Jurnal Pendidikan Dasar, 9 (1), Juni 2021

\title{
CIVIC ENGAGAMENT KAMPOENG BACA PELANGI COMMUNITY IN EDUCATINGAND REDUCING PSYCHOLOGICAL IMPACTS FOR CHILD VICTIMS OF THE LOMBOK EARTHQUAKE
}

\author{
Ahmad Hudori $^{1}$, Dewi Gunawati ${ }^{2}$, Triana Rejekiningsih ${ }^{3}$ \\ ${ }^{1,2,3}$ Universitas Sebelas Maret \\ Jl. Ir. Sutami No.36, Kentingan, Kec. Jebres, Kota Surakarta, Jawa Tengah 57126 \\ 1 ahmadhudori04@gmail.com², dewigunawatiuns@yahoo.co.id, 3 triana_rizq@staff.uns.ac.id
}

\begin{abstract}
This paper tries to discuss the Kampoeng Baca Pelangi community as an effort to educate and reduce the impact of the natural disaster in Lombok for child victims. Then his command aimed to explore the form of the Kampoeng Baca Pelangi community in educating and reducing the psychological impact for children who were victims of the Lombok earthquake. Indonesia is a country prone to natural disasters. Based on data compiled from the National Disaster Management Agency (BNPB), it is stated that during 2020, starting from January 1, 2020, to December 28, 2020, there were 2,925 natural disasters throughout Indonesia. This paper uses a qualitative approach with a case study method. The findings in this study are in terms of educating children about the impact of natural disasters, the Kampoeng Baca Pelangi community takes steps such as (1) Identifying children affected by disasters and planning appropriate activities for them, (2) providing time for children to discuss disasters, (3) careful group discussions for children, (4) encourage children not to consume news too much, (5) encourage children to continue if possible. Meanwhile, to reduce the impact of natural disasters, the Kampoeng Baca Pelangi community applies traumatic counseling strategies. Traumatic counseling is divided into three stages, (1) the initial stage of counseling, (2) the middle stage of counseling, (3) the final stage of counseling.
\end{abstract}

Keywords: Kampoeng Baca Pelangi community, psychological impacts, child victims, Lombok Earthquake

\begin{abstract}
Abstrak: Tulisan ini membahas tentang Komunitas Kampoeng Baca Pelangi sebagai upaya mengedukasi dan mengurangi dampak bencana alam di Lombok bagi anak-anak korban bencana alam di Lombok. Kemudian tujuan dari penelitian ini adalah untuk menggali bentuk komunitas Kampoeng Baca Pelangi dalam mendidik dan mengurangi dampak psikologis anak-anak korban gempa Lombok. Indonesia merupakan Negara yang rawan bencana. Berdasarkan data yang dihimpun Badan Nasional Penanggulangan Bencana (BNPB), disebutkan selama tahun 2020, terhitung mulai 1 Januari 2020 hingga 28 Desember 2020, terdapat 2.925 bencana alam di seluruh Indonesia. Penelitian ini menggunakan pendekatan kualitatif dengan metode studi kasus. Temuan dalam penelitian ini adalah dalam hal mengedukasi anak tentang dampak bencana alam, masyarakat Kampoeng Baca Pelangi mengambil langkah-langkah seperti (1) mengidentifikasi anakanak yang terdampak bencana dan merencanakan kegiatan yang tepat untuk mereka, (2) menyediakan waktu untuk anak-anak diskusi mengenai bencana, (3) menyediakan kegiatan diskusi kelompok untuk anak, (4) menyarankan anak-anak untuk tidak terlalu banyak mengonsumsi berita, (5)mendorong anak-anak untuk melanjutkan jika memungkinkan. Sedangkan untuk mengurangi dampak bencana alam, komunitas Kampoeng Baca Pelangi
\end{abstract}

65| J P D, p - I S S N : $2252-8156$, e - I S S N : 2579-3993 
Jurnal Pendidikan Dasar, 9 (1), Juni 2021

menerapkan strategi konseling traumatis. Konseling traumatis dibagi menjadi tiga tahap yaitu (1) konseling tahap awal, (2) konseling tahap tengah, (3) konseling tahap akhir.

Kata Kunci: Masyarakat Kampung Baca Pelangi, dampak psikologi, anak-anak korban bencana alam Lombok.

Sumber: ICEHoS - International Conference onEducation, Humanities, and Social Science

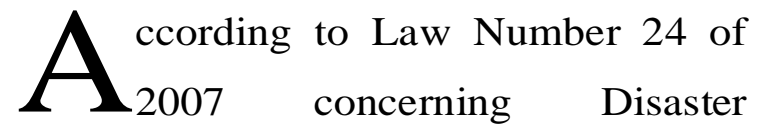

Management, a disaster is defined as a series of events that disturbs and threatens the livelihoods and livelihoods of the surrounding community caused by natural, nonnatural, or human factors that cause human casualties, damage to the environment, loss of property. objects, and the impact on psychological. Indonesia is a country that is prone to natural disasters. We can see this from a series of natural disasters that have hit, which have come and gone in various regions in Indonesia. Based on data compiled from the National Disaster Management Agency (BNPB), it is stated that during the 2020 period, starting from January 1, 2020 to December 28, 2020,there were 2,925 natural disasters in all regions of Indonesia. From these natural phenomena, it proves that Indonesia is a country that is prone to natural disasters. One type of natural disaster that often occurs in Indonesia is an earthquake.
Earthquakes are natural disasters that cannot be predicted when and where they will occur. No human or any sophisticated technology can predict the time and place where an earthquake will occur, because earthquakes are purely God's power. No exception to the earthquake that hit the island of Lombok in August 2018, with a magnitude of 6.5 and 7.0 which destroyed buildings in almost all areas on the island of Lombok, from public facilities such as mosques, schools, hospitals. Government offices to private buildings such as residents' houses leveled to the ground. Stalking from Wikepedia Indonesia, earthquakes are vibrations or vibrations that occur on the earth's surface due to the sudden release of energy from within which creates seismic waves. Earthquakes are usually caused by the movement of the earth's crust (the earth's plates).

In addition to causing damage or destruction to public and private buildings, earthquake natural disasters also cause large numbers

66| J P D, p - I S S N : 2252 -8156, e - I S S N : 2579-3993 
of people to die. Not only casualties, the earthquake that occurred in Lombok also resulted in injured victims who were crushed by collaps edbuilding sat the time of the earthquake to deep trauma suffered by victims, mainly children. The earthquake that occurred in August 2018 was the largest earthquake ever to occuron the island of Lombok. An extraordinary event like this experienced by someone who cannot be anticipated or predicted can certainly cause menta ldisturb anceorcause prolonged deeptrauma.

One of the public facilities that was destroyed due to a natural disaster was a school. The long period of school closure makes children unable to go to school so that this can be an additional psychological burden on the child. This condition can cause a decrease in mental quality as a result of the traumatic incident (Nugroho et al, 2012). The disruption of the education process has a severe impact, because it can lead to the deprivation of the basic right to education for millions of children and endanger their future. The earthquake has been responsible for child deaths, as well as physical and psychological injuries to children and disruption of education delivery services (HodaBaytiyeh,2017).

Education is a shared responsibility between the Government 67| J P D, p - I S S N : 2252-8156, e - IS S N : 2579-3993 and society. Without the support and active participation of the community, education will never be successful or optimally implemented as expected in the goals of national education. In Law Number 20 of 2003 concerning the National Education System Article 54 paragraph (1) states that the participation of the community in education includes the participation of individuals, groups, families, professional organizations, entrepreneurs and community organizations in the implementation and control of the quality of educational services. So to achieve all of this, of course, it requires active involvement from the community or community organizations.

The involvement of citizens insocial life is a hope for realizing the ideals of society (Gusmadi, 2018). Civic Engagement is one of the main concepts in Community Civics to be able to participate in public life. Jacoby \& Associates (2009) stated that "civic engagement encompasses actions wherein individuals participate in activities of personal and public concern that are both 
individually life enriching and socially beneficial to the community". This opinion explains that citizen involvement includes actions where individuals participate in activities of personal and public concern that individually enrich each other and benefit society socially. Why civic engagement appears to have a positive impact on various areas of a person's life, such as their health and well-being, the answer lies in the capacity to be a citizen. Citizen engagement allows for the formation of identities, to provide a sense of agency and purpose, and to build skills and relationships (Pancer,2015).

Thanks to what has been described above about the importance of handling victims, especially children, as well as efforts to educate and educate about the impact of the earthquake that occurred. Because in addition to healing physical wounds, the protection of victims of natural disasters does not only cover that, but what is equally important is the handling of traumatic wounds or the improvement of human emotional conditions as a result of the disaster and ensuring that they still get one o ftheir basic rights interms of education.
To ensure that children who are victims of the Lombok earthquake can still enjoy basic education services, a group of punk children who are members of the East Warior community took the initiative to form a forum that can be used as a source of learning and at the same time mental recovery for children who are victims of the Lombok earthquake, namely Kampoeng Baca Pelangi which is located in East Merece Hamlet, Selat Village, Narmada District, West Lombok Regency, Prov.NTB. Selat Village is one of the worst villages in West Lombok Regency which was affected by the earthquake. This activity was carried out based on information from one of the members who were also victims of the earthquake that their hamlet had not been touched by assistance from the government as of August until the establishment of Kampoeng Baca Pelangi in November2018. Kampoeng Baca Pelangi was the only disaster post. nature that accommodates, initiates, and distributes donations from both the internal East Warrior community to

68| J P D, p - I S S N : $2252-8156$, e - I S S N : $2579-3993$ 
friends from outside the community in various cities in Indonesia (Prasetya, 2020). Based on what has been described above, collaboration from the community as one of the forces that arise and develop from the community itself is expected to be actively involved in helping the government to support the growth and development of Indonesian children, one of which is in the field of education and being involved in educate and reduce the psychological impact felt by natural disasters thatoccur.

\section{LITERATURE REVIEW}

\section{Civic Engagement}

According to Turrini, citizen involvement can empower the community to be significantly involved in any process that encourages citizens to be able to make decisions according to the environmental situation (Zakaria, 2020). Then another opinion was conveyed by Adler and Goggin (2005), which defined civic engagement asa reference to how citizens participate in community life to improve the condition of others or to help shape the future of the community. So it can be said that civic engagement is a way for the community to be able to play an active role in encouraging individual or communitydevelopment.

Education in Emergency Situations and Educational Conditions after the Lombok Earthquake

Education in an emergency means providing schools in humanitarian emergencies including conflict or war, natural disasters and health-related crises, such as the Ebola outbreak. In 2017alone, 75 million children and adolescents experienced educational disruptions, received low-quality education or dropped out of school altogether. Emergencies can interfere with a child's education for years. This means children miss important learning and lose their safe places when they are in particularly traumatic situations. Education in emergency situations can be categorized as non-formal education. Non- formal education channels held in Indonesia whose impact can support the development of Indonesian society. Non- formal education is provided for members of the community who need educational services that function as asubstitute, enhancement, and / or complement to formal education in

69| J P D, p - I S S N : $2252-8156$, e - I S S N : 2579-3993 
order to support lifelong education (Article 26 Paragraph 1, Law on National EducationSystem).

In an article published by Theirworld, it is explained that education in an emergency situation is important because without education, childhood, youth may be lost due to child labor (under age), child marriage, recruitment by armed groups or other threatening activities. their soul. A child who has not been in school for more than one year is unlikely to return to school. Girls are $2.5 \%$ more likely to drop out of school than boys. In addition, there are several other reasons that support the importance of education in an emergency, which are asfollows:

1. A sense oftogetherness In emergency situations, education can give neglected or traumatized children a structured or directed feeling. Safe places to play and study can help children recover and get back to their normal routines.

2. Well-being and survival skills Schools can also be places to provide important health and safety information, such as hand washing, landmine awareness and other survival skills.

3. Breaking the cycle of poverty Getting children back to learning means offering better opportunities to break the cycle of poverty or longterm conflict. Educating children contributes to building peace and restoring the conditions of societythat are unfavorable dueto the disasters that hit. This helps children develop the skills and knowledge they need to build a safe and strong community and economy when they reach adulthood.

Then look at the condition of education in West Nusa Tenggara (NTB), which, when viewed from the quality of education in NTB, is second from the bottom, namely 33 out of 34 provinces in Indonesia (Radar Lombok, July 25, 2019). This condition was exacerbated by the devastation of the Province of NTB and the island of Lombok in particular by the earthquake in 2018 which resulted in the damage to various buildings including schools which hampered educational services for the nation'schildren.

The earthquake that occurred made children temporarily unable to enjoy educational services due to damaged school buildings and facilities and the fear of aftershocks that still loom over the community and government 
which could happen at any time. Therefore, that ultimately forced the policy makers to temporarily close schools until the deadline was unable to while seeing developments in the situation and conditions in the future. Based on data obtained from the National Secretariat for Disaster Safe Education (SPAB) as of August 12, 2018 , there were a total of 606 education units that were reported to be damaged, and a total of 977 classrooms were declared severely damaged. A total of 17 students died, 56 were injured, and 19 people had to be hospitalized.

\section{Community}

The term community is derived from the Latin communitas which comes from the root word communis which means society, public or many people. The Indonesian Wikipedia explains the notion of community as a social group of several organisms that share an environment, generally having the same interests and habitats.

In a human community, the individuals within it can have similar intentions, beliefs, resources, preferences, needs, risks and a number of other conditions. According to McMillan and Chavis (1986) say that a community is a collection of its members who have a sense of belonging, are bound to one another and believe that the needs of members will be met as long as the members are committed to being together. Meanwhile, according to Mac Iver, community is termed a life association or community and is interpreted as a community area marked by several levels of social group ties to one another. The existence of a community is usually based on several things, namely locality and community sentiment.

The elements in the sentiment community according to Mac Iver are as follows:

1. Feelings

The element of affection arises as a result of the actions of members in the community who identify themselves with the group due to common interests.

2. Covered

Covered is defined as awareness of the roles and responsibilities of community members in the group.

3. Need eachother

The element of mutual need is defined as a feeling of dependence on the community, both physical andpsychological.

Based on what has been

71| J P D, p - I S S N : 2252 - 8156 , e - I S S N : 2579 - 3993 
described above, it can be understood that a community is a group of people or a group of people with the same vision or goal which is usually formed because of one commonality between its members.

\section{Psychologica lImpact of Natural Disasters}

Discussing natural disasters certainly does not escape the impact it brings to people who are victims of these natural disasters. One of the impacts felt by victims of natural disasters is a psychological impact. Psychological impact consists of two words, namely impact and psychological. Impact is a strong influence that results in both positive and negative consequences (Partanto, 1994). The word psychological is an adjective from psychology which means psychiatric. According to Irwanto (2002), if translated psychology means the study of the soul. So it can be understood that the psychological impact is a strong influence that appears on a person's soul caused by a certain event which in this case is a natural disaster.

Psychologically, there are two aspects that arise in victims of natural disasters as a result of natural disasters, 72| J P D, p - I S S N : 2252-8156, e - IS S N : 2579-3993 namely emotional aspects and cognitive aspects. The emotional aspect is characterized by symptoms such as shock, fear, sadness, resentment, guilt, shame, helplessness, loss of emotions such as feelings of love, intimacy, joy or attention to everyday life. Whereas in the cognitive aspect, the changes experienced by victims such as chaotic thoughts, misperceptions, decreased ability to make decisions, decreased concentration and memory, and blamed themselves.

\section{METHODOLOGY}

\section{Research Strategy}

Writing this article uses a qualitative research type with a case study method. According to Nasution, qualitative research is essentially observing people in their life environment, interacting with them, trying to understand their language and their interpretation of the world around them (Sugiyono, 2015:205). Meanwhile, the case study method is a research design found in many fields, especially evaluation, where the researcher develops an indepth analysis of a case, often a program, event, activity, process, or 
one or more individuals. Cases are limited by time and activity, and researchers collect complete information using various data collectionprocedures based on predetermined time (Creswell, 2016).

\section{DISCUSSION}

Adler and Goggin (2005) define civic engagement as what refers to the way citizens participate in community life to improve the conditions of others or to help shape the future of the community. So it can be said that civic engagement is a way for the community to be able to play an active role in encouraging individual or community development. One of the communities that is active in social and humanitarian activities is the Kampoeng Baca Pelangi Community. Kampoeng Baca Pelangi is a social group that is actively involved in helping to educate and reduce the psychological impact experienced by children as a result of the earthquake that occurred on the island of Lombok. Kampoeng Baca Pelangi is a learning platform that was established or started its activities on November 5, 2018, which started with post-Lombok trauma healing activities. Then the activity continued every week or after the children from school, until finally many parties responded well (Kampoeng Baca Pelangi).

Smawfield defines disasters as sudden and catastrophic events that result in substantial material damage, loss and harm. Disasters do not spread evenly around the world with the Asia-Pacific region having the highest death rates. Women and children are often the most vulnerable populations in disaster situations, especially those in lower socioeconomic communities (Carol Mutcha \& Elizabeth Gawith,2014).

Of the various types of natural disasters thatexist, earthquakes are the most unpredictable and most damaging to the built environment. In addition, anearthquake that occurs can disrupt social services in general as well as schools, students and the education process in particular, with many negative effects.The collapse of school facilities during an earthquake can result in mass casualtyevents that have a real effect on the livesand hopes of thousands of children (Hoda Baytiyeh,2017).

On August 5, 2018 an earthquake measuring 7 on the 
Richter scale struck Lombok Island, Indonesia with a depth of $32 \mathrm{~km}$, after a series of earthquakes since early July 2018 with a magnitude of 6.4 SR (Dwidiyanti, 2018). The earthquake that occurred on the island of Lombok is a rare and interesting phenomenon to understand its behavior. The fluctuating pattern of seismicity creates panic and confusion, especially for the people who live in Lombok, as well as on the islands of Sumbawa and Bali. Based on data from the National Disaster Management Agency (BNPB), overall the damage caused by the 2018 Lombok earthquakeis 71,962 damaged housing units, 671 damaged educational facilities, 52 health facilities, 128 worship facilities and infrastructure facilities. Meanwhile, the victim data is that 460 people died, 7,733 were injured, 417,529 people were displaced (Kompas.com - 23/09/2018).

Child victims may have an increased susceptibility to adverse outcomes when compared to adults, their young age can influence how they interpret these events, and they may be influenced by a variety of different or broader stressors (Robyne Le Brocque, 2016). In the post-disaster recovery process, the need for research that focuses on children is essential to improve the effectiveness of prevention and recovery strategies for children and adolescents affected by disasters. Effective recovery programs are essential for ensuring the survival of children and also because the changing contexts after a disaster can change the direction of children's development (Fremaan et al., 2015). How the recovery process carried out can have a positive impact on the long-term welfare of children who are victims of natural disasters.

Psychological trauma after a natural disaster will further exacerbate psychological conditions or problems that existed before the earthquake occurred. Distress related to natural disasters will last long after the incident (Dwidiyanti, 2018). Then the psychological impact caused by natural disasters that occur can be very common in children and can cause mental health, behavioral, and academic problems in the long term. Children are prone to a number of mental health difficulties after a traumatic event, including the development of symptoms of posttraumatic stress disorder (Robyne Le 
Brocque, 2016). This condition will worsen if it is not detected early and handled properly, thus requiring mental health services (trauma healing) (Dwidiyanti,2018).

Furthermore, the form of involvement of the Kampoeng Baca Pelangi community in helping educate children who are victims of the Lombok earthquake to be able to overcome the trauma they feel is carried out by the followingsteps:

1. Identify children affected by the disaster and plan appropriate activities forthem.

Activities undertaken include class discussions, individual counseling, small group counseling, or family therapy. From class discussions, and by maintaining close contact with teachers and parents, volunteering community members can help determine which students may need more intense counseling service than identified identification.

2. Provide time for children to discuss disasters.

Depending on the situation, a tutor from the community may be able to guide the discussion in the group. The purpose of group discussions is to help children better understand the disasters they are experiencing. In addition, it also encourages children to develop effective ways of coping, find that their peers share similar questions, and develop peer supportnetworks.

3. Approach a group discussion for the most affected child with caution Discussions with children most affected by natural disasters and should be accompanied by volunteers from thecommunity.

4. Encourage children not to consume too muchnews.

Watching endless reruns of disaster footage can be even more stressful. Although children want to be kept informed, especially if they have loved ones in the affected area.Taking a break from watching thenews can reduce their stress and anxiety.It would be better to consume news about disasters in the company of parents so that children can be supervised while being given an understanding. Another step that can be taken is that news about the disaster that has occurred can be conveyed by volunteers from the community in a lighter language and does not put pressure on the feelings and thoughts of the children.

5. Encourage the child to continue with the routine if possible. 
Carrying out daily routines and schedules as usual will be very helpful for children or students to give themselves a break from constantly thinking about the disasters that have befallen them.

Community involvement in helping educate children about the psychological impacts they feel as a result of natural disasters that hit will certainly have a very positive influence on their understanding of disasters and the impacts caused by disasters that occur, especially psychologicalimpacts.

Furthermore, in an effort to reduce the trauma or psychological impact felt by child victims of the Lombok earthquake, the Kampoeng Baca Pelangi Community implemented a traumatic counseling strategy. Sutirna explained that what is meant by traumatic counseling is a counselor's effort to help clients who have experienced trauma through the process of personal relationships so that clients can understand them selves in relation to the trauma problem they are experiencing and try to deal with it as best as possible. Thepurpose of traumatic counseling is to make behavioral change sinclientssoas to allow their lives to be more productive and satisfying, emphasize more on the client's recovery in the pre-trauma state and being ableto adapt to new environmental conditions (Rahmatetal, 2020).

Then like the counseling process in general, the process in the traumatic counseling strategy is divided into three stages, namely the initial stage of counseling, the middle stage (work stage), and the final stage of counseling (Rahmat, 2020). The followingis an explanation of the traumatic counseling strategy as an effort to reduce the psychological impact felt by child victims of the Lomboke arthquake:

1. Early stage of counselling At this early stage, the counseling process starts from the time the counselor meets the counselee so that the counseling process goes on and finds a definition of the problem experienced by the victim (client). What is done by the counselor in this counseling process are as follows: (a) building traumatic counseling relationships that involve clients who have experienced trauma; (b) clarify and define the trauma problem; (c) exploring alternative assistance to overcome trauma problems; and (d) negotiating contracts.

2. Mid-stage counseling

76| J P D, p - I S S N : $2252-8156$, e - IS S N : 2579-3993 
Based on the clarity of the client's trauma that was agreed upon at an early stage, the next activity is to confront: (a) exploration of the trauma experienced by the client; (b) what assistance will be provided based on reassessing what has been explored about the client's trauma.

3. Final stage counselling

At this stage, counseling is characterized by the following: (a) a decrease in client anxiety which is known after the counselor asks about his state of anxiety; (b) there is a change in client behavior towards a more positive, healthy and dynamic direction; (c) there is aclear purpose in life in the future with a clear program; (d) the occurrence of a positive change in attitude towards the problems they are experiencing, can self-correct and eliminate an attitude that likes to blame the outside world such as parents, friends, and unfavorable circumstances.

\section{CONCLUSION}

From the above research it can be said that community involvement in educating children related to the impact of natural disasters that occurred is very important and has a positive impact on children who are victims of the Lombok earthquake, because the presence of the community in this situation as a volunteer is needed considering the condition of people. parents who are both victims and the limitations of the community's ability to educate children about the disasters that hit them and ensure that children can still enjoy education or lessons even in an emergency. In addition, community involvement in educating the psychological impact felt by child victims has a very positive effect on the psychological condition ofchildren, maintains and restores their condition after the disaster that strikes, and participates in maintaining and ensuring that children's growth and development continues to run well.

\section{REFERENCE}

Adler, R.P. \& Goggin, J.(2005). What

Do We Mean By “Civic

Engagement"?. Journal of

Transformative Education.3, (3): 236-253.

C Freeman, K Nairn \& M Gollop. (2015). Disaster impact and recovery: what children and young people can tell us. New Zealand Journal of Social Sciences Online, 10:2, 103-115, DOI:

10.1080/1177083X.2015.1066400 Creswell. John W. (2016). Research

77| J P D , p - I S S N : $2252-8156$, e - I S S N : $2579-3993$ 
Design (Edisi 4). Yogyakarta:

Pustaka Pelajar. Sugiyono. 2016.

Memahami Penelitian Kualitatif.

Bandung: Alfabeta CV.

Fahmi Arif Zakaria. (2020).

Keterlibatan warga negara dalam

pembangunan berkelanjutan

melalui program desmigratif.

Jurnal Civic Education, Vol. 4

No.1 55-60

Gusmadi, S. (2018). Keterlibatan Warga

Negara (Civic Engagement) alam

Penguatan Karakter Peduli

Lingkungan. In JUPIIS: Jurnal

Pendidikan Ilmu-Ilmu Sosial (Vol.

10). $\quad$ https://doi.org/10.24114/

jupiis.v10i1.8354.

Hayatul Khairul Rahmat. (2020).

Konseling Traumatik: Sebuah

Strategi Guna Mereduksi

Dampak Psikologis Korban

Bencana Alam. Jurnal Mimbar,

Vol.6 No 1. 34-44.

Irwanto. (2002). Psikologi Umum.

Jakarta: Gramedia Pustaka

Utama.

Karliani, E. (2014). Membangun Civic

Engagement Melalui Model

Service Learning untuk

Memperkuat Karakter Warga

Negara. Jurnal Pendidikan

Pancasila dan
Kewarganegaraan, 27(2), 7178.

Meidiana Dwidiyanti .(2018).

Gambaran Risiko Gangguan Jiwa pada Korban Bencana Alam Gempa di Lombok Nusa Tenggara Barat. Journal of Holistic Nursing And Health Sience. Volume1, Nomor2, Oktober2018

Pancer, S. M. (2015). The Psychology of Citizenship and Civic Engagement. New York: Oxford University Press.

Partanto, P. A. (1994). Kamus Ilmiah Populer. Surabaya: Arloka.

Prasetya, Arrizal. (2020). Respon Masyarakat Terhadap Program Kampoeng Baca Pelangi dan Citera Komunitas Punk East Warrior di Desa Selat, Kec. Narmada, Lombok Barat. Program Studi Ilmu Komunikasi, Universitas Mataram.

Robyne Le Brocque dkk. (2016). Schools and Natural Disaster Recovery: The Unique and Vital Role That Teachersand Education Professionals Play in Ensuring the Mental Health of

78| J P D, p - I S S N : $2252-8156$, e - IS S N : 2579-3993 
Jurnal Pendidikan Dasar, 9 (1), Juni 2021

Students Following Natural

Disasters. Journal of

Psychologists and Counsellors

in Schools, Volume 27, Issue 1

, June 2017, pp. 1 - 23

DOI:https://doi.org/10.1017/jgc.2

016.17

Sogand Torani. (2019). Pentingnya pendidikan tentang bencana dan keadaan darurat: Artikel ulasan. Journal of Education and Healt Promotion, Doi: 10.4103 / jehp.jehp_262_18

Yayu Hardiyanti Isnin. (2018). Peran Komunitas Mengajar Terhadap Pendidikan Di Kecamatan Muncang Provinsi Banten (Studi Kasus: Komunitas Gerakan Ayo Mengajar). Jurusan Pendidikan Ilmu Pengetahuan Sosial Fakultas Ilmu Tarbiyah Dan Keguruan Universitas Islam Negeri Syarif Hidayatullah Jakarta. 